\title{
RANDAI ART AS LOCAL WISDOM IN CREATING LOCAL TOURISM INNOVATION In KUANTAN SINGINGI REGENCY
}

\author{
Made Devi Wedayanti S.AP., M.Si
}

\author{
Public Administration Faculty of Social and Political Sciences Riau Islamic University \\ Email: madedeviwedayanti@soc.uir.ac.id
}

\begin{abstract}
Seni Randai Kuantan, is a heritage art from traditional culture that used to grow and develop in Kuantan Singingi Regency. Randai in the Kuansing area called Randai Kuantan. Kuansing Regency has cultural tourism, one of which is Randai Performing Arts attractions. Randai Performing Arts is used as a tourist attraction because Randai is a unique folk art that is unique in delivering messages and entertainment. Therefore, Randai performance art can also be used as an added value innovation for local tourism managers so that it can increase the number of tourist visits. However, Randai is still rarely implemented and young women from Kuantan singing district have started to know that Randai art can become one of the mainstay alternatives to attract tourists to visit Kuantan Singingi Regency. This research is a type of qualitative research. The source of this research data is primary data obtained from interviews with informants and key informants. Data analysis is done by data reduction, data presentation and conclusion drawing. The conclusion of this study is based on respondents' responses to randai art attractions, respondents gave responses that the Randai show was interesting, the readiness of the community to make randai art a tourist attraction, the community responded that it was ready to make randai displayed as a tourist attraction and became a characteristic in Kuantan Tengah Subdistrict Kuantan Singingi Regency .
\end{abstract}

Keywords: Tourism Innovation, Local Wisdom., Randai.

\section{Introduction}

Riau Province nicknamed the "Yellow Green Earth" is located very strategically in allied countries, so that the government and its people adhere that Riau Province will take a strategic role in the field of economy and culture. The agreement between the government and the community is set out in the Vision Riau 2020, in which Riau aims to be the center of Malay economic and cultural growth in the stretch of Southeast Asia in 2020.

Kuantan Singingi Regency (Kuansing) is one of the districts in Riau Province, Indonesia. Kuansing Regency is also called Rantau Kuantan or as an overseas area of the Minangkabau people (Rantau nan Tigo Jurai). In everyday life, the Kuansing people use Minangkabau customs and language even though Kuansing is geographically located in the Riau Province Region which is actually Malay. This regency is in the southwestern part of Riau Province and is a division of Indragiri Hulu Regency. As the Rantau Nan Tigo Jurai area, in Malay culture there is a Randai Dance. Randai is one of the traditional games in Minangkabau which is played in groups by forming a circle, then stepping slowly, while delivering stories in the form of songs alternately. Randai combines song, music, dance, drama and martial arts into one. Playing Randai is based on famous folklore, local music traditions, and martial arts. Randai was previously a form of Minangkabau folk art, but not a form of theater (people). 
At first Randai was a form of dance art. Randai began to be known in the villages along the Kuantan river of Indragiri Riau, around 1937. At that time the economic condition of the people in the area was quite good. The price of sap is quite expensive, moreover many farmers or sap cultivators are given subsidies by the Dutch. This good economy has encouraged the coming of Minangkabau migrants to the area, hoping to get a better job or come to trade. The first Randai performed in the Kuansing area was Randai Cindur Mato. This Randai is played by Minangkabau migrants together with the Kampar people. Their Randai performances are almost all the same as the Randai shows in Minangkabau. Randai Kuantan, basically is one of the traditional arts that developed in the province of Riau. There are so many uniqueness that we can see in this tradition. In addition, the Kuantan Randai art is also used as a means to introduce a new vision that will be achieved by Riau Province, namely as one of the centers of Malay culture in Southeast Asia.

When viewed from the form and uniqueness of this folk art, it is not wrong if the Riau Provincial Culture and Tourism Office decided to choose to use the Kuantan Randai art as one of the cultural promotion media. Where various Kuantan Randai art performances have been held in several countries, to tell various historical stories, or stories about the progress of development in progress in the province of Riau.

Randai Kuantan, is a heritage art from traditional culture that used to grow and develop in Kuantan Singingi Regency. One of the tourist areas in the province of Riau, which also holds a lot of various arts and cultural performances. The uniqueness of this art, we can witness in a variety of performance activities, which are also widely implemented in various points in the province of Riau. Besides being one of the mainstay tourist attractions, generally the art performances held for about 4 hours are also crowded and are visited by many people around Singingi district who want to find entertainment. Randai Kuantan is a unique art that shows a variety of folklore, which is performed in a traditional art theater performance. This art, is also played by a group of people who number around 15 to 30 people in one performance. There are several important roles, such as story characters and other supporting roles, in art performances which are also played by the majority of young people who are also often called by the name Randai Bujang Gadi. Art is synonymous with various behaviors and attractions of the players who are able to invite laughter from the viewers who watched it. This is because there are various unique jokes and are also unique, which certainly will be a dish for us to enjoy in the Kuantan Randai art show. One of the attractions and being able to invite humor in this art, one of them, is a character played in the traditional theater arts. We will see where the actors in the game, it seems that they deliberately changed positions. That is where male players intentionally act as women, and vice versa, female players who play themselves in order to be men. There are so many stories and folklore that are performed alternately in each of the Kuantan Randai art performances. One of the folk stories that is often staged in the Kuantan Randai art, namely a legendary story with the title "Sutan Nan Garang". One of the folklore that developed in Singingi Regency, and told about the life of a young man who was brave, and had a face that was so beautiful. Some people in the Randai Kuantan art performance group also served as players in traditional musical instruments. Among the musical instruments that 
accompanied the various performance activities were Piaual, Gedang, Biola, Seruling, Harmonika, Rebana, as well as Lapri musical instruments, to accompany various folk songs performed at the Kuantan Randai art performance.

Kuantan Singingi Regency is a division of Indragiri Hulu Regency which was formed based on Law No. 53 of 1999, concerning the Establishment of Pelalawan District, Rokan Hulu, Rokan Hilir, Siak, Natuna, Karimun, Kuantan Singingi and Batam City. Kuantan Singingi Regency consists of 12 (twelve) districts with an area of 7,656.03 km2, which is in the position between 0000-1000 South Latitude and 101002 - 101055 East Longitude.Randai is a traditional Kuantan community art form in the form of oral, which contains stories about the life of the Kuantan community everyday, for example local folklore, economy, and government. Randai is a descending inheritance of the Kuantan community that still exists today. The following is the art in Kuantan Singingi Regency:

Table 1.1

List of Arts in 2018 Kuansing Regency

\begin{tabular}{|l|l|l|}
\hline No & \multicolumn{1}{|c|}{ Art } & \multicolumn{1}{c|}{ Types of Art } \\
\hline 1 & Randai & Traditional \\
\hline 2 & Kayat & Traditional \\
\hline 3 & Saluang Dangdut & Modern \\
\hline 4 & Silat & Traditional \\
\hline 5 & Rebab & Traditional \\
\hline
\end{tabular}

Source: Kuantan Singingi District Tourism Office 2018

From the table above, it can be seen that Kuantan Singingi Regency has five arts, one of which is Randai Performing Arts. Randai Performing Arts is used as a tourist attraction because Randai is a unique performance in the delivery of messages and entertainment. Randai players are generally male, while women are not allowed to play Randai. So that the role of women is replaced by men. Then men dress like a woman. The following are the names of the Randai groups in Kuantan singingi:

Table 1.2

List of Randai Groups in 2018 Kuansing District

\begin{tabular}{|c|l|l|}
\hline No & \multicolumn{1}{|c|}{ Randai Group Name } & \multicolumn{1}{c|}{ Village / Origin } \\
\hline 1 & Randai Dang Gadunai & Sentajo \\
\hline 2 & Randai Dendang Duduk & Banjar Inuman \\
\hline 3 & Randai Mekar Sejati & Puluk Busuk Jaya \\
\hline 4 & Randai R.tunas Harapan & Koto Inuman \\
\hline 5 & Randai Bunga Selankai & Sigaruntang \\
\hline 6 & Randai Duduk & Pulau Sipan \\
\hline 7 & Randai Candra Kelana & Pasar Usang \\
\hline 8 & Dendang Maimbau & Pasar Baru \\
\hline 9 & Randai Mustika & Koto Kombu \\
\hline 10 & Randai Tuas sekako & Serosa \\
\hline 11 & Randai tali bajalin tigo & Kompe berangin \\
\hline 12 & Randai Bungo serumpun & Tanjung medan \\
\hline 13 & Randai tunas muda & Gunung toar \\
\hline
\end{tabular}


Cultural tourism in Kuantan Singingi Regency is one of them is Randai Performing Arts tourist attraction. Randai Performing Arts is used as a tourist attraction because Randai is a unique performance in the delivery of messages and entertainment. Therefore, Randai performance art can also be used as an added value for the singing singing district so that it can increase the number of tourist visits. Kuantan Singingi Regency displays Randai Performing Arts usually when there are folk parties and certain events as entertainers of the community and as attracting people to visit the event, but now this is still rarely implemented and even now it is something foreign to young men in Kuantan district is singing, whereas Randai Art can be one of the mainstay alternatives to attract tourists to visit Kuantan Singingi Regency.

Gudykunst and Kim (in Westi 2011: 5) Culture means accumulative deposits of knowledge, experience, beliefs, values, attitudes, meanings, hierarchy, religion, choice of time, role, space relations, broad concepts and material objects or possessions and maintained by a group of people or generations. Similarly, culture can mean a system of knowledge intended by a number of people in a large group.

According to Marriam et al (in Westi 2011: 5) The role of art and culture in the development of tourism discussing the role of art has the following functions: (1) As a giver of beauty and pleasure, (2) As an entertainer, (3) As a symbolic offering, (4) as a physical response provider, (5) As a manifestation of the norms of community life, (6) As an affirmation of social institutions and religious ceremonies, (7) As a contribution to the continuity and stability of culture, (8) As a contribution of social integration, (9) As a communication tool.

Ismayanti (2010: 15) Cultural tourism is a type of tourism that is based on the mosaic of places, traditions, arts, ceremonies and experiences that portray a nation and ethnic group with society, which reflects the diversity and identity of the community or the nation concerned. Cultural tourism makes use of culture as a tourism and cultural potential that can be distinguished into three forms, namely ideas, activities, and artifacts.

\section{a. Ideas (Ideal Forms)}

The form of cultural ideal in the form of culture in the form of a collection of ideas, ideas, values, norms, regulations, which are abstract, cannot be touched or touched. This form of culture lies in the head or in the minds of the people. If the community expresses the idea in writing, then the location of the ideal culture is in an essay and books produced by the author of the community.

\section{b. Activity (Action)}

Activity is a form of culture as a pattern of human behavior in society. This form is often called a social system. This social system consists of other human activities according to certain patterns based on customary behavior. Its concrete nature, occurs in everyday life, and can be observed and documented.

c. Artifacts (Works) 
Artifacts are a form of physical culture in the form of the results of activities, actions, and works of all humans in society as well as objects or things that can be touched, seen and documented. Its nature is the most concrete among the three forms of culture.

Sadarmayanti, (2005: 12) The aim of the tourism development program is to develop and expand the diversification of national tourism products and quality based on community empowerment, art, culture and local natural resources while maintaining the preservation of traditional arts and culture and environmental sustainability local.

Travel Attractions are in fact other words of tourism but according to Indonesian government regulations in 2009 said tourism objects are no longer relevant to mention a tourist destination then the word "Tourist Attraction" is used to find out what the meaning and meaning of tourist attraction in below are some definitions / understanding of Tourist attraction according to some experts:

Based on the Law of the Republic of Indonesia No. 10 of 2009, Travel Attraction is explained as everything that has uniqueness, ease, and value in the form of diversity of natural wealth, culture, and man-made results that are targeted or tourist visits.

1. A. Yoeti in his book "Introduction to Tourism Science" in 1996 stated that tourist attraction or "tourist attraction", a term that is used more often, is everything that attracts people to visit a particular area.

2. Nyoman S. Pendit in his book "Tourism Science" in 2006 defines tourist attraction as everything that is interesting and valuable to visit and see.

From some of the above understanding, it can be concluded that tourist attraction is everything that has attraction, uniqueness and high value, which is the destination for tourists to come to a certain area.

Hamidy (2002: 13) said that it was seen from the origin of the word Randai which means eg or eg. Associated with the randai art show, the actor plays the role as the technique played.

Hamidy (2002: 21) Besides that, randai comes from the word andai-andai which means talking to other people and connotating poorly. But the other person has also replied to the conversation so that the point is a heated discussion and usually there is always a mediator who then looks for a solution agreed by both parties. It is this life and randai art performances are similar to actual situations and circumstances. Interestingly, randai kuantan singingi shows its own color and figure when compared to randai from its original place and randai kuantan is a performance art that is full of the value and prominence of the Kuantan area.

Hamidy (2002: 13) Randai Stories are full of the values and norms of social life and culture of the Kuantan community, usually at the end of the story always insert messages, the moral form of life must be frugal, humble, if lead jealousy, not easily discouraged as conveyed through the story of randai bujang paman, or personally the daughter of adam dewi or the personal sultan of abiding and almost all stories of randai depicting socio-cultural norms and values. 
The purpose of this research is to find out whether Randai art can be made as a local wisdom innovation in Kuantan Singingi Regency?

\section{Methodology}

This study used qualitative research methods. The source of this research data is primary data obtained from interviews with informants and key informants. The Key Informant in this study was the Head of the Tourism and Culture Office of Kuantan Singingi Regency, and the key informant in this study were 7 of 13 leaders of Grub Randai in Kuantan Singingi and Pemuda Pemuda Regencies in Kuantan Singingi District. Data analysis is done by data reduction, data presentation and conclusion drawing. The source of the data is obtained from the use of indicators as follows:

Table 1.3

List of 2018 Research Indicators and Sub Indicators

\begin{tabular}{|c|c|c|c|}
\hline No & Variable & Indicator & Sub Indicator \\
\hline \multirow[t]{4}{*}{1} & \multirow{9}{*}{$\begin{array}{l}\text { Randai Art as Local } \\
\text { Wisdom in Creating } \\
\text { Local Tourism } \\
\text { Innovation in Kuantan } \\
\text { Singingi Regency }\end{array}$} & \multirow{5}{*}{$\begin{array}{l}\text { The response of } \\
\text { tourists to the } \\
\text { appeal of Randai } \\
\text { art }\end{array}$} & 1. Storyline \\
\hline & & & 2. Dance \\
\hline & & & 3. Music \\
\hline & & & 4. Use of Language \\
\hline \multirow[t]{5}{*}{2} & & & 5. Clothing \\
\hline & & \multirow{4}{*}{$\begin{array}{l}\text { Community } \\
\text { Readiness }\end{array}$} & 1. Place \\
\hline & & & $\begin{array}{ll}\text { 2. } & \text { Schedule } \\
& \text { Appearance }\end{array}$ \\
\hline & & & 3. Randai players \\
\hline & & & 4. Smart equipment \\
\hline
\end{tabular}

\section{Discussion}

Based on the responses of respondents about Randai Art as a tourist attraction from the responses of respondents to the statements and questions given. Of the two indicators above, the tourist responses to tourist attraction and community readiness are divided into nine subindicators regarding the responses of respondents as follows:

1. Indicator of tourist response which is divided into five sub-indicators of questions and statements which include storyline, dance, music, language use and clothing used in the show shows that the randai art is considered attractive and unique by respondents because it highlights the peculiarities of Kuantan Regency Singingi and is considered to have the potential to be made an innovation in the arts tourism of local wisdom in Kuantan Singingi Regency.

2. Indicators of community readiness which are divided into four sub-indicators of questions and statements which include the venue, performance schedule, randai players / members, randai performance equipment used in art 
performances show the results that the community's readiness in terms of place, appearance schedule and equipment has been ready to make randai art as a potential to be made an innovation in the arts tourism of local wisdom in Kuantan Singingi Regency. However, for the sub-indicators of the randai players, they are still in the category quite ready by respondents because there are still many young people who know the art of local wisdom so that for generations of players to be worried about extinction, they prefer and know about modern art.

Overall, of the nine items of questions and statements in the form of interviews that were distributed by the author, this shows that randai art as local wisdom is said to be feasible as the potential for tourism innovation in Kuantan Singingi Regency. With improvement suggestions in the sub indicator of randai players to provide more information to young people in Kuantan Singingi Regency so that they know and care about Randai Art which is the local wisdom in Kuantan Singingi Regency.

\section{Conclusion}

Kuantan Singingi Regency (Kuansing) is one of the districts in Riau Province, Indonesia. Kuansing Regency is also called Rantau Kuantan or as an overseas area of the Minangkabau people (Rantau nan Tigo Jurai). Randai is a traditional dance of the Minangkabau people of West Sumatra, Indonesia. Randai in the Kuansing area is closely related to the arrival of Minang migrants to the area. Randai in the Kuansing area called Randai Kuantan. The first Randai performed in the Kuansing area was Randai Cindur Mato. This Randai is played by Minangkabau migrants together with the Kampar people. Their Randai performances are almost all the same as the Randai shows in Minangkabau. Randai Kuantan, basically is one of the typical arts of the people that has a lot of uniqueness. However, in its implementation, Randai has now begun to be unrecognized by young women in Kuantan Singingi district. so that it is worried about its extinction. In fact, if it is well managed, it can be used as an art of local wisdom to create tourism innovation in Kuantan Singingi Regency. From the Nine Sub Indicators, only 1 sub Randai Player Indicator from the Community Readiness Indicator which is still not ready makes randai as an art of local wisdom in Kuantan Singingi Regency. So it can be concluded that Randai Art can be made as a Local Wisdom Innovation in Kuantan Singingi Regency. Authors' suggestions in this regard are as follows:

1. Created by a group of Randai arts administrators in Kuantan Singingi regency and carried out routinely by taking turns by the randai group grub in Teluk Kuantan City as the center of the youth group of Kuantan Singingi Regency. So that it can better introduce Randai Art to young people of Kuantan Singingi Regency.

2. For the randai player group, the storyline is more varied, such as folklore, community economic story, the latest news in the present. 


\section{BIBLIOGRAPHY}

Hamidy, UU, 2002. Kuantan Singingi Malay Indigenous People. UIR press, Pekanbaru Ismayanti, 2010. Introduction to Tourism. PT Gramedia Widiasarana Indonesia. Jakarta Pendit, Nyoman.S. 2006. Tourism Science. PT. Pradnya Paramita. Jakarta Sadarmayanti. 2005. Building Culture and Tourism. CV. Advanced Mandar. Yoeti, Oka A. 1996. Introduction to Tourism Sciences. Space. Bandung Indonesia 